\title{
Sınıf Öğretmenlerin Kendilerine Yönelik Dijital Okuryazarlık Düzeylerinin Farklı Değişkenler Açısından İncelenmesi
}

\author{
Investigation of Digital Literacy Levels of Classroom Teachers in Terms of Different Variables
}

\author{
Hanife KESKIN* (D), Gonca KÜÇÜK (iD)
}

\begin{abstract}
ÖZ
Toplumun ilerlemesi adına çağa uygun bireylerin yetişmesi, ancak eğitimle mümkündür. Dijital okuryazarlık becerisini kazanarak eğitim ortamlarında kullanmak eğitimi daha etkili ve çağdaş yapacaktır. Bu çalışma, sınıf öğretmenlerinin kendilerine yönelik dijital okuryazarlık düzeylerini farklı değişkenler açısından ölçmek amacıyla gerçekleştirilmiştir. Ayrıca bu araştırma ile sınıf öğretmenlerinin dijital okuryazarlık düzeyleri üzerinde cinsiyetlerinin, eğitim durumlarının, hizmet sürelerinin, mezun oldukları lise türünün, yaşlarının, bilgisayara erişim imkanlarının etkisinin olup olmadığı ortaya koyulmak istenmiştir. Dijital okuryazarlığın alt boyutları kaynak kullanabilme, uygulama kullanabilme ve destek olarak ele alınmıştır. Belirlenen bu değişkenlerin kişilerin dijital okuryazarlığına olan etkisi göz önünde bulunarak gerekli tedbirler alınabilir veya bu noktalara dikkat edilerek planlamalar yapılmalıdır. Bu amaçla çalışmada Ocak ve Karakuş (2018) tarafından geliştirilen "Öğretmen Adaylarının Dijital Okuryazarlık Öz-yeterliliği Ölçeği (ÖADOÖÖ)” olarak adlandırılan Cronbach-Alpha iç tutarlık sayısı 0. 908 olan likert tipi ölçek kullanılmıştır. Veriler SPSS 22.0 programı ile incelenmiştir. Çalışma Şanlıurfa Eyyübiye Ahmet Hamdi Akseki İlkokulu’nda görev yapan 38 sınıf öğretmeni ile gerçekleştirilerek çalışmaya gönüllü katılım sağlanmıştır. Araştırma sonrasında öğretmenlerin dijital okuryazarlık öz yeterliliklerinin fazla olduğu sonucuna ulaşılarak cinsiyet ve mezun olunan lise türüne ait birer alt boyutları üzerinde anlamlı farklılık gösterdiği gözlemlenmiştir.

Anahtar Kelimeler: Dijital okuryazarlık, sınıf ögretmenleri, internet.

ABSTRACT

For the progress of the society, it is possible to raise individuals who can keep up with the age, only through education. Acquiring digital literacy skills and using them in educational environments will make education more effective and contemporary. This study was carried out to measure the digital literacy levels of classroom teachers in terms of different variables. In addition, with this research, it was aimed to reveal whether gender, education status, length of service, type of high school they graduated from, age, and computer access opportunities have an effect on the digital literacy levels of classroom teachers. The sub-dimensions of digital literacy were handled as resource use, application use and support. Considering the effect of these determined variables on the digital literacy of individuals, necessary measures can be taken or plans should be made by paying attention to these points. For this purpose, a Cronbach-Alpha likert type scale with an internal consistency of 0.908, called the "Digital Literacy Self-Efficacy Scale of Pre-service Teachers" developed by Ocak and Karakuş (2018), was used. The data were analyzed with the SPSS 22.0 program. The study was carried out with 38 classroom teachers working in Şanlıurfa Eyyübiye Ahmet Hamdi Akseki Primary School, and voluntary participation was ensured. It was concluded from the study that the digital literacy self-efficacy of the teachers was high, and there were significant differences in each sub-dimension of gender and the type of high school graduated.
\end{abstract}

Keywords: Digital literacy, classroom teachers, internet.

\section{Gíriş}

Ülkeler vatandaşlarına çağdaş ve mutlu bir yaşam sunabilmenin ancak çağın gerisinde kalmayarak, değişen ve gelişen bilgiye olan erişimin sürekli olmasıyla mümkün olacağının farkındadırlar. Bilim ve teknik alanlarında ilerlemek, sosyal ve ekonomik kalkınma gibi birçok alanda başarılı olmak ancak bilgiye ulaşarak ve onu kullanarak mümkün olacaktır. Çağdaş ülkeler sırasında yer almak ancak dünyada var olan bilgi birikiminin gerisinde kalmayarak mümkün olacaktır. Eğitim yoluyla toplumda bilgiye ulaşmak, bilgiyi etkin şekilde kullanmak ve bilginin yaygınlık kazanmasını sağlamak mümkündür (Önal, 2010, s. 106).

Okuma yazması olan kişiler için genellikle "okuryazar" kavramı kullanılmaktadır. Yaşam boyu sürekli olarak uygulanan okuma yazma uygulamaları okuryazarlık olarak adlandırılmaktadır. Okuryazar bireylerin gündelik yaşamda karşılaşılan olay, olgu ve

Dokuz Eylül Üniversitesi, Buca Eğitim Fakültesi, Temel Eğitim Bölümü

Sorumlu Yazar/Correspondence Author: Hanife KESKIN

E-posta/E-mail: hanife.keskin@deu.edu.tr

Geliş Tarihi/Received: 26.10 .2021

Kabul Tarihi/Accepted: 15.11.2021

Ç. Yayınlanma Tarihi/Online Published: 30.11.2021 
kavramalarla ilgili gerekli değerlendirmeleri yapmalarının yanında kendilerini geliştirmeleri bir gereklilik olarak görülür (Yılmaz, 1989, s. 49). Geleneksel yapı ile yeni yapının birlikte değerlendirilmeye çalışıldığı bu uzun sürecin üstüne düşünülmüştür. Var olan bilgiyi edinmenin yanında güncel gelişmelerin takibinin sağlanmasının da önemli bir yere sahip olduğu gözlemlenmiştir. Önceden elde edilen bilgilerle yeni elde edilen bilgilerin ilişkilendirilmesi ve bunlardan yeni sonuçlar elde edilmesinde okuryazarlık kavramı önemli bir yere sahiptir. Toplumun sürekli değişerek dönüşüm içerisine girmesiyle okuryazarlık kavramı da yeni işlevler kazanmıştır (Önal, 2010, ss. 104-105). Teknolojinin günden güne hızla değişmesi, bireylerin bu doğrultuda kazanmaları gereken becerilerinin farklılık göstermesine yol açmaktadır. Böylelikle bu sonuç bireylerin teknolojiyi yakından ve sürekli olarak takip etmelerini gerekli kılmıştır (Yontar, 2019, s. 816).

Aksu Bektaş ve Alver (2020)'in “Medya Okuryazarlığı Dersine İlişkin Öğrenci Tutumları ile Öğretmen ve Öğretmen Adayı Görüşlerinin Değerlendirilmesi” adlı çalışmalarında Türkoğlu (2010)'nun çalışmasına dayanarak dijital teknolojilerin süreç içinde gelişerek ve yenilenerek günlük yaşamın içerisinde daha belirgin bir şekilde yer alması ile tüm dünyanın teknoloji üzerinde ortak bir kültür oluşturmasını sağladığına, dijital kültür olarak adlandırılan bu kültürün, çağın zamanla neden olduğu bir yaşam tarzı ve alışkanlıkların toplamı olarak değerlendirildiğine; günümüzde, teknolojinin hızlı ilerleyişinin dünyanın teknolojik bir hal almasında etkisinin büyük olduğuna değinilmiştir. Dijitalleşme, internetin meydana çıkışı ile her konuda yer edinmiş ve bilginin hâkim olduğu toplumda dijital kültür vazgeçilmez bir yapı oluşturmuştur.

Yontar (2019)'ın yapmış olduğu çalışmada dijital okuryazarlık kavramının tanımları, dijital kaynaklardan sağlanan bilgiye ulaşabilme, bu kaynaklardan elde edilen bilgilerle mevcut bilgileri karşılaştırarak yorumlayabilme birçok açıdan değerlendirme yapabilme şeklinde izah edilmiştir. Bu doğrultuda dijital okuryazar birey dijital kavramlara hâkim olup bu kavramları ve dijital teknolojiyi etkili şekilde kullanan, dijital uygulamaları doğru şekilde uygulayabilen bireylerdir.

Ocak ve Karakuş (2019) dijital okuryazarlık kavramını dijital araçları ve yazılımları kullanma olarak ifade edilmesinin yanlışlığını dile getirmişlerdir. Dijital okuryazarlıkta karmaşık, bilişsel, sosyolojik ve duygusal beceriler yer almaktadır. Bu alana özgü yeterliliklere ulaşmak bireylerin dijital ortamlarda rahat çalışabilmelerini sağlayan nitelikleri kazanmakla mümkündür. Dijital okuryazarlık faaliyetleri içerisinde grafik ekranlarda yer alan yönergeleri okumak, bu ortamda birçok anlamlı materyaller meydana getirebilmek, dijital ortamda karşılaşılan bilginin kalitesini ve geçerliliğini yorumlayarak değerlendirmede bulunmak gibi faaliyetler yer almaktadır.

İnternet bilgiye ulaşmanın yanında farklı birçok amaç için de oldukça fazla kullanılmaktadır. Sosyal yaşamın içinde yer alan alışveriş yapma, boş zamanları değerlendirme, haberleri ve gündemi takip etme gibi birçok aktiviteye ulaşım internet ile gerçekleşmektedir. İnternetin bu denli yoğun kullanımı akıllara internetin güvenilirliğine dair birçok soruyu getirmektedir. Ortaya çıkan bu sorunlara bakıldı̆̆ında ise sergilenen korumacı tavrın bireyler üzerinde oluşturduğu internete karşı savunmasız kalma hali oldukça dikkat çekmektedir. Korumacı tavrın bir neticesi olan savunmasız kalma hali sonucunda genç bireylerin internet ortamlarına karşı genel bir önyargı içinde olmalarına ve olumsuz değerlendirmelerin hâkim olduğu bir sürece tanık olmalarına neden olacağı göz önünde bulundurulmalıdır. Bu korumacı tavırdan uzaklaşarak internet kullanımını tüm yönleri ile ele alıp sorgulayan, olumlu ve olumsuz yönlerini dikkate alarak gerekli değerlendirmeyi yapabilen, çeşitli yorumlar getirerek bu konuda bireylerin kendi düşüncelerine sahip olmalarını sağlamaya odaklanılmalıdır. Böylelikle yaşamın merkezinde yer alan interneti doğru ve etkin kullanıp aynı zamanda internet içeriği üretimi noktasında bilgi ve beceriye sahip olmak mümkündür. Bu yaklaşım ışığında dijital okuryazarlık kavramı değerlendirilmelidir (Karabacak ve Sezgin,2019, s. 325). Dijital okuryazarlığın en önemli kazanımlarından olan interneti güvenli bir şekilde kullanmak, doğru bilgiyi seçebilmek, internet yoluyla bilginin hızlı bir şekilde yayılarak yanıltıcı sonuçlar ortaya çıkarması gibi durumlardan etkilenmemesini sağlayacaktır. Bu yüzden dijital okuryazarlığın bu kazanımına oldukça dikkat çekilmeli, bireylerin bu kazanımları edinmeleri sağlanmalıdır. Aynı zamanda dijital okuryazarlık bu ortamda bilginin üretilmesi sürecine de katkı sağlayacaktır (Hamutoğlu, Canan Güngören, Kaya Uyanık ve Gür Erdoğan, 2017, s.411). Zamanla değişen koşullar sonrası teknolojinin hayatımızın her alanına girmesiyle dijital okuryazarlığın eğitim öğretimin her basamağında eğitime entegre edilerek sürecin sağlıklı yaşanması sağlanmalıdır. Bu sürecin sağlanması, tüm toplumlar için çağın gereği olarak, bir zorunluluk halini almıştır. Türkiyedeki dijital okuryazarlığa dünyadaki gelişmelere paralel olacak şekilde eğitim alanında da yer verilerek bu konu üzerinde durulmuştur (Karabacak ve Sezgin, 2019, ss. 325 - 328).

Karabacak ve Sezgin (2019)'in çalışmasında, Gilster (1997)'ın dijital okuryazarlı̆̆ı, sunumun bilgisayar aracılığıyla yapıldığında birçok kaynaktan gelen bilgileri çoklu formatlarda anlama ve kullanma becerisi şeklinde ifade ettiğine yer verilir. Böylelikle dijital okuryazarlık kavramı, basitçe yapılan ifadesinin ötesine geçerek araştırılıp elde edilen 
verileri yaşamda kullanma yeteneği olarak ele alınır. Yetenek olarak değerlendirilen okuryazarlık kavramı, dijital okuryazarlık kavramı ile birlikte çok daha farklı yetkinlikleri içeren bir yapı haline gelmiştir. Bu noktada yetkinlikleri geliştirmek adına eğitim programlarına büyük ihtiyaç duyulduğu ifade edilebilir. Özellikle eğitim alanında bireylerin dijital okuryazarlık alanındaki yetkinliklerini arttıracak faaliyetler planlanarak bu süreç adına yapılacak girişimlerin tüm kademelerde gerçekleştirilmesine ihtiyaç vardır (Karabacak ve Sezgin, 2019, s. 328).

Budak ve Öztürk (2019)'ün yapmış oldukları çalışmada dijital okuryazarlık kavramının teknik, bilişsel ve sosyalduygusal olmak üzere üç ana boyuttan oluştuğu görülmektedir. Bu doğrultuda uygulama becerilerinde yetkin olmak, teknik boyutu; araştırma, değerlendirme ve araştırma süresince eleştirel düşünme konusundaki yetkinlik, bilişsel boyutu; iletişim kurarken saygılı ve uygun bir dil kullanma, kişisel güvenlik ve mahremiyeti korumak adına kişisel verileri gizli tutmak gibi davranışlar ise sosyal-duygusal boyutu oluşturmaktadır.

İnsanların teknoloji alanındaki kazanması gereken yetkinlikler, teknolojinin hızla değişmesi sonucunda günden güne farklılık göstermektedir. Bu durum teknolojinin yakından ve doğru şekillerde takibini gerekli kılmaktadır. Gelişen teknoloji ile bilgiyi elde etmek kolaylaşırken bu konuda birçok beceriye sahip olmak gerekli hale gelmiştir. Bu da eğitimin çağın şartlarına göre sık sık gözden geçirilmesini ve geliştirilmesini mecburi kılmıştır. Öğrenme öğretme ortamlarının bu doğrultuda tasarlanması gerekmektedir (Yontar, 2019, s. 816).

Ocak ve Karakuş (2019) çalışmalarında elde ettikleri bilgiler doğrultusunda geleneksel eğitim ortamının ve geleneksel materyallerinin yanında dijital okuryazarlık beceri düzeyinin artmasını sağlayacak sınıf içi uygulamaların, sınıfı ve dersi öğrenci için daha etkili ve merak uyandırıcı konuma dönüştüreceğini ifade etmişlerdir. Dijital okuryazarlığa eğitim kademelerinin tümünde yer verilmeli ve eğitim ortamlarında etkili bir şekilde kullanımı sağlanmalıdır. Böylece sürekli gelişen dünyada rol alan bireyler dijital okuryazarlık becerisinin yararlarını ilerleyen yıllarda iş ve özel hayatlarında görerek daha başarılı olacakları yapılan çalışmada belirtilmiştir.

Çağımızda bilginin büyük bir güç olması bilgiye ulaşabilen, bilgiyi doğru şekilde kullanarak üretim odaklı bireylere olan gereksinimi arttırmıştır. Bu yolda bireyleri yetiştirmek adına eğitim sistemleri de değişiklik yapma yoluna girmişlerdir. Eğitim ortamlarının bilgiye ulaşılabilir alanlar olması, programların da gerekli özellikleri taşıması bu noktada büyük önem taşımaktadır. Öğrenciye sağlanan bu imkânlardan öğrencinin en doğru ve bilinçli şekilde faydalanması gerekmektedir. Öğretmenin bu konuda öğrenciye liderlik yapabiliyor olması ve gerekli donanıma sahip olması da önemli bir noktadır. Öğretmenin bilgiyi sunan konumunda olmaktan ziyade bilgiye ulaşma yollarını öğrencinin keşfetmesini sağlayan kişi konumunda olması gerekir. Eğitim ortamlarını teknoloji ile destekleyerek öğrencilerin bilgiye ulaşıp öğrenmeyi öğrenmeleri; yaratıcılık, eleştirel düşünme, problem çözme, karar verme, gibi düşünme becerileri konusunda aktif olmaları sağlanmalıdır. Teknoloji ile eğitim süreçlerini başarılı şekilde kaynaştırmak son derece önem arz etmektedir. İşin odak noktasında yer alan öğretmenlerin eğitimi ise son derece önemlidir. Öğretmenlerin gerekli becerileri edinmeleri adına hizmet içi eğitimlerin düzenlenmesi, öğretmen adaylarının ise eğitim aldıkları ortamların bu becerileri edinmelerini sağlayacak şekilde organize edilmesi gerekmektedir. Öğretmenlerin teknolojiyi yakından takip ederek öğrencilerin teknolojiden en verimli şekilde yararlanabilmelerini sağlayacak rehberliği yapmaları gerekmektedir (Atav, Akkoyunlu, Sağlam, 2006, ss.38-39).

Acar (2015), dijital araçların kullanımının çok küçük yaş gruplarına kadar indiğini bunun da teknolojiyi doğru kullanma konusunda birtakım sorunlara yol açtı̆̆ını, öğretmen ve diğer aile üyelerinin bu noktada bilinçli olmaları ve gerekli yönlendirmeyi yaparak teknoloji ile çocukların doğru, verimli ilişkiler kurmasını sağlamaları gerektiğini ifade etmiştir. Dijital okuryazarlık kavramı bu noktada çok önemlidir. Bireylerin kişisel fayda sağlamalarının yanında toplum için bilinç geliştirmeye yönelik katkılar sağlamasına da yardımcı olmalıdır. Öğretmen adaylarının ve öğretmenlerin çağın gereklilikleri doğrultusunda kendilerini, dijital okuryazar olmanın yanında, bu alana yönelik üretici, uygulayıcı bireyler olacak şekilde geliştirmeleri gerekmektedir. Türkiye’de de dünyanın büyük bir kesiminde görüldüğü gibi özellikle çocukların, daha okul çağına gelmeden internet teknolojileriyle çok erken karşılaşmış olması, bu konuda alınması gereken tedbirler başta olmak üzere ilgili birçok konuyu gündeme getirmiştir. Gençlerin de internet ortamında geçirdikleri zaman dikkate alındığında bu konuya yönelik eğitim konusunda düzenlemelerin yapılmasının gerekli ve kaçınılmaz olduğu görülmüştür. Ülkemizde Millî Eğitim Bakanlığı başta olmak üzere ilgili diğer kurumların internet kullanımında bilinçli tutum sergileme yönündeki çalışmaları arttırmak için dijital okuryazarlık konusundaki eylemleri dikkat çekmektedir (Karabacak ve Sezgin, 2019, s. 331).

2012 yılında alana özgü yetkinliklerin kazandırılması için MEB Fırsatları Artırma ve Teknolojiyi İyileştirme Hareketi (FATIH)'ni başlatarak okullara ait teknolojik alt yapıyı geliştirip öğrenci ve öğretmenlerin teknolojiye uyum sağlamalarını ve teknolojiyi kullanma becerilerini geliştirerek öğrenme süreçlerine olumlu katkı sağlamayı 
hedeflemiştir. Böylelikle MEB 2018 programlarında bulunan dijital yetkinlik, Türkiye Yeterlilikler Çerçevesinde (TYÇ) 2015 yılında yayınlanarak vurgulanmıştır. Öğretim programları dijital yetkinlikleri barındırmaktadır. Fakat öğretmen ve öğretmen adaylarının dijital okuryazarlık düzeylerinin durumu net olarak bilinmemektedir. Karakuş ve Ocak (2019), günümüz şartlarında eğitim verecek olan öğretmen ve öğretmen adaylarının yetişmekte olan kuşağa etkili bir eğitim sağlayabilecek düzeyde teknolojiye hâkim ve dijital okuryazar olmaları gerektiğini vurgulamıştır.

Dijital okuryazar olan bireylerden değişen teknolojiye karşı uyum göstermeleri beklenir. Günümüzde bireylerin bu becerilere sahip olmaları onların hayatlarında bu becerileri daha etkin kullanmalarını sağlayarak hayatlarının birçok noktasında olumlu katkılar sağlayacaktır. Hayatımızda önemli yeri olan ve zaman geçtikçe önemi daha da artacak olan teknoloji için gerekli eğitimler verilerek, ülkenin geleceği adına önemli adımlar atmak mümkündür. Eğitim alanında bu yönde yapılması gereken değişiklikler ve yenilikler iyi planlanmalıdır. Millî Eğitim Bakanlığı’nın okullarda teknoloji ile eğitimi bir araya getirmek amacıyla FATİH Projesini (Fırsatları Arttırma ve Teknolojiyi iyileştirme) hayata geçirmesi önemli bir adım olmasına rağmen araştırmalar, projenin etkili kullanılması yönünde eksikliklerin mevcut olduğunu bizlere göstermektedir. Öğretmen, öğretmen adayları ve öğrenciler projenin başarısında önemli rollere sahiptir. Bu noktada öğretmen, öğretmen adaylarının ve öğrencilerin dijital okuryazarlık becerilerinin geliştirilmesi, büyük öneme sahiptir. Bu nedenle gerekli eğitim programlarının düzenlenmesi, öğretmenlerin öğrencilere teknoloji konusunda doğru örnek olarak onlara liderlik yapabilmeleri son derece önemlidir (Üstündağ, Güneş, Bahçivan, 2017, s. 21).

\section{ARAŞTIRMANIN AMACI VE ÖNEMİ}

$\mathrm{Bu}$ araştırmada genel amaç olarak öğretmenlerin kendilerine yönelik dijital okuryazarlık düzeylerinin farklı açılardan belirlenmesi hedeflenmiştir. Bu amaç doğrultusunda bazı alt problemler de araştırmaya dahil edilmiştir. Öğretmenlerin medya okuryazarlık düzeylerinin cinsiyete, yaşa, hizmet sürelerine, mezun olunan liseye ve bilgisayara olan erişime göre anlamlı bir farklılık gösterip göstermediği incelenmiştir. Çakmak (2019)'ın "Öğretmenlerin Medya Okuryazarlık Düzeylerinin İncelenmesi” adlı çalışmasında Altun (2005)'dan yararlanarak ifade ettiği düşünce doğrultusunda insanların ihtiyaç duyduğu bilgiye çok kısa bir sürede ulaşabilmeleri, teknolojinin sürekli değişerek ilerlemesi ile dijital okuryazarlığın giderek önemli bir beceri olarak yer edinmiş olması, özellikle iletişim alanındaki teknolojik ilerlemelerin insan hayatında dijital ortamların daha fazla yer edinmesini sağladığı ve bunun sonucunda daha fazla kitleye daha kolay ulaşıldığı söylenebilir. İnsan hayatında bu denli önemli yer edinmiş olan dijital kaynaklar, insanların dikkatli ve bilinçli yaklaşması gereken bir yapıdır. Dijital kaynakların farklı amaçlar için kullanılması sonucunda ortaya çıan her bilgi doğru olarak kabul edilmeyip üzerine düşünülmesi, eleştirilmesi, sorgulanması gereken unsurları oluşturur. Bu noktada bireylerin bilinçli olup doğru davranışları sergileyebilmeleri gerekmektedir. Bunun için Ulusoy (2018)'un da belirttiği gibi gerekli eğitimin bu bilince sahip öğreticiler tarafından verilmesi dijital okuryazar bireylerin oluşmasında önemli bir yere sahiptir. Bireylerin bu yeterliliği barındırmaları da eğitimcilerin medya okuryazarllğı konusunda gerekli yeterliliğe sahip olması ile mümkündür. Yapılan bu araştırmada öğretmenlerin dijital okuryazarlık düzeylerini gösteren veriler saptanmış ve sunulmuştur. Bu çalışmanın öğretmenlerin dijital okuryazarlık becerinin mevcut durumu hakkında bilgi vermesi, konu üzerinde çalışan kişi ve kuruluşların araştırmalarına fayda sağlaması ve literatüre katkıda bulunması beklenmektedir (Çakmak, 2019, s. 304).

\section{Problem Cümlesi}

Sınıf öğretmenlerin dijital okuryazarlık öz-yeterlilik düzeyleri nasıldır? Bazı değişkenlerin dijital okuryazarlık özyeterlilik düzeyleri üzerinde etkisi var mıdır?

\subsection{Alt Problemler}

1. Sınıf öğretmenlerin dijital okuryazarlık beceri düzeyleri nasıldır?

2. Cinsiyet değişkenini, sınıf öğretmenlerinin dijital okuryazarlık öz-yeterliklerinde anlamlı bir boyutta farklılığa sebep olmakta midır?

3. Sınıf öğretmenlerin eğitim durumları dijital okuryazarlık öz yeterlikleri üzerinde anlamlı bir farklılık oluşturmakta mıdır?

4. Mezun olunan lise türü, sınıf öğretmenlerinin dijital okuryazarlık öz yeterliliklerinde anlamlı bir boyutta farklılı̆ga sebep olmakta mıdır? 
5. Sınıf öğretmenlerin hizmet süreleri, dijital okuryazarlık öz-yeterlikleri üzerinde anlamlı bir farklılığa neden olmakta midır?

6. Sınıf öğretmenlerin yaşları, dijital okuryazarlık öz yeterlilikleri üzerinde anlamlı bir farklılığa neden olmakta midir?

7. Sınıf öğretmenlerin bilgisayara erişim imkânları, dijital okuryazarlık öz-yeterlikleri üzerinde anlamlı bir farklılığa neden olmakta mıdır?

\section{YÖNTEM}

\section{Araştırmanın Modeli}

Gerçekleştirilen bu araştırma, tarama modeline uygun bir şekilde yapılmıştır. Bir grubun hedeflenen özelliklerini belirlemek için yapılan çalışmalarla sonuçların elde edilmesini sağlayan araştırmalara tarama araştırması denilmektedir (Büyüköztürk, Kılıç, Akgün, Karadeniz ve Demirel, 2014, 14). Bu araştırmada Şanlıurfa Eyyübiye Ahmet Hamdi Akseki İlkokulu’nda görev yapan 38 öğretmen dijital okuryazarlık hakkında kendilerine yönelik görüşleri ortaya koymuşlardır ve ortaya koyulan bu görüşler çeşitli değişkenler açısından incelenmiştir.

\section{2. Çalışma Grubu}

Araştırmanın çalışma grubunu 2020-2021 eğitim-öğretim yılında Şanlıurfa Eyyübiye Ahmet Hamdi Akseki İlkokulu’nda görev yapan 38 sınıf öğretmeninden oluşmaktadır. Çalışma grubunun oluşturulmasında gönüllülük esası ön planda tutulmuştur.

Tablo 1. Çalışma Grubunda Yer Alan Öğretmenlerin Demografik Özellikleri

\begin{tabular}{lccc}
\multicolumn{1}{c}{ Demografik özellikler } & & Frekans & Yüzde \\
Cinsiyet & Kadın & $(\mathrm{N})$ & 57,9 \\
& Erkek & 22 & 42,1 \\
Eğitim Durumunuz & Lisans & 16 & 92,1 \\
& Yüksek Lisans & 35 & 7,9 \\
& Doktora & 3 & 0 \\
& Genel Lise & 0 & 36,8 \\
& Anadolu Lisesi & 14 & 44,7 \\
Mezun Olduğunuz Lise Türü & 17 & 15,8 \\
& Anadolüğretmen Lisesi & 6 & 0 \\
& Sosyal Bilimler Lisesi & 0 & 0 \\
& Fen Lisesi & 0 & 2,6 \\
Hizmet Süresi & Meslek Lisesi & 1 & 68,4 \\
& $0-5$ yll & 26 & 28,9 \\
& $6-10$ yll & 11 & 2,6 \\
Yaş & $11-15$ yıl & 1 & 13,2 \\
& $20-24$ & 5 & 47,4 \\
\multirow{2}{*}{ Bilgisayara Erişim İmkanı } & $25-29$ & 18 & 36,8 \\
& $30-34$ & 14 & 2,6 \\
\hline
\end{tabular}

\section{Veri Toplama Aracı}

Yapılan araştırmada gerekli verileri toplamak adına Ocak ve Karakuş (2018) tarafından geliştirilen "Öğretmen Adaylarının Dijital Okuryazarlık Öz-yeterliliği Ölçeği (ÖADOÖÖ)” olarak adlandırılan likert tipi ölçek kullanılmıştır. 5'li likert tipiyle hazırlanan ve 35 maddeden oluşan ölçekte üretim, kaynakları kullanabilme, uygulama, destek alt boyutları olmak üzere 4 alt alan bulunmaktadır. Ölçekte anne ve baba eğitim durumu yer almaktadır, fakat bu çalışma 
öğretmenler üzerinde yapıldığı için anne ve baba eğitim durumunun belirtilmesi gerekli görülmeyip araştırmacı tarafından uygulanan ölçekte kullanılmamıştır.

Araştırmada kullanılan ölçeğin güvenirliğinin belirlenmesi amacıyla hem ölçeğin bütünü için hem de alt boyutları için hesaplanan Cronbach a değerleri; 35 maddeden oluşan ölçeğin bütünü için .958 on maddeden oluşan üretim alt boyutu için .908 , on maddeden oluşan kaynak kullanabilme için .883, dokuz maddeden oluşan uygulama alt boyutu için .902 , beş maddeden oluşan destek alt boyutu için .888 olarak tespit edilmiştir. Bu durum hem ölçeğin bütününde hem de alt boyutlarında güvenilirliğin yüksek derecede olduğunu ifade etmektedir.

\section{Verilerin Analizi}

Verilerin hesaplanmasında SPSS 22 istatistik programı kullanılmıştır. Demografik özellikler frekans (N) ve yüzde (\%) değerleri ile açıklanmıştır.

Veri dağılımının normal olup olmadığı Shapiro-Wilks testi ile kontrol edilmiş üretim ve uygulama kullanabilme alt boyutlarının normal dağılım gösterirken, kaynak kullanabilme ve destek alt boyutlarının normal dağılım göstermedikleri tespit edilmiştir. Ardından cinsiyet ve bilgisayara erişim imkânın üretim ve uygulama kullanabilme alt boyutları üzerinde anlamlı farklılığa sebep olup olmadığını saptamak için T-Testi; kaynak kullanabilme ve destek alt boyutları üzerinde anlamlı farklılığa sebep olup olmadığını saptamak için Mann-Whitney U testleri kullanılmıştır. Eğitim durumu, mezun olunan lise türü, hizmet süresi değişkenlerinin üretim ve uygulama alt boyutları üzerinde anlamlı farklılığa neden olup olmadığını saptamak için Tek Yönlü Varyans Analizi (ANOVA) Testi; kaynak kullanma ve destek alt boyutları için Kruskal-Wallis Testi kullanılmıştır. Tüm analizlerde anlamlılık düzeyi $\mathrm{p}<, 05$ şeklinde kabul edilmiştir.

\section{Bulgular ve Yorumlar}

Bu bölümde araştırmanın amaçları doğrultusunda ulaşılan bulgular, tablolar halinde açıklanmıştır.

\section{Sinı öğretmenlerin dijital okuryazarlı beceri düzeyleri nasıldır? .}

Tablo 2. Ölçeğin birinci boyutu (üretim) ile ilgili yüzde, frekans ve madde ortalamaları

\begin{tabular}{|c|c|c|c|c|c|c|}
\hline Boyutta yer alan maddeler & & 1 & 2 & 3 & 4 & 5 \\
\hline \multirow{2}{*}{$\begin{array}{l}\text { Dijital ortamda öğrenci düzeyine uygun değerlendirme çalışmaları } \\
\text { hazırlayabilirim. }\end{array}$} & $\mathrm{f}$ & 1 & 3 & 7 & 18 & 9 \\
\hline & $\%$ & 2.6 & 7.9 & 18.4 & 47.4 & 23.7 \\
\hline \multirow{2}{*}{$\begin{array}{l}\text { Dijital ortamda öğrencinin konuyu pekiştirmesini sağlayacak uygulamalar } \\
\text { hazırlayabilirim. }\end{array}$} & $\mathrm{f}$ & 0 & 4 & 11 & 15 & 8 \\
\hline & $\%$ & 0 & 10.5 & 28.9 & 39.5 & 21.1 \\
\hline \multirow{2}{*}{$\begin{array}{l}\text { Farklı öğrenme stillerine sahip öğrencilere yönelik dijital materyal } \\
\text { hazırlayabilirim. }\end{array}$} & $\mathrm{f}$ & 1 & 5 & 9 & 16 & 7 \\
\hline & $\%$ & 2.6 & 13.2 & 23.7 & 42.1 & 18.4 \\
\hline \multirow{2}{*}{ Dijital ortamda öğrenci ödevlerini değerlendirebilirim. } & $\mathrm{f}$ & 0 & 2 & 6 & 20 & 10 \\
\hline & $\%$ & 0 & 5.3 & 15.8 & 52.6 & 26.3 \\
\hline \multirow{2}{*}{$\begin{array}{l}\text { Öğrencinin daha hızlı bilgi paylaşabilmesi için dijital kaynak } \\
\text { kullanabilirim. }\end{array}$} & $\mathrm{f}$ & 1 & 4 & 8 & 16 & 9 \\
\hline & $\%$ & 2.6 & 10.5 & 21.1 & 42.1 & 23.7 \\
\hline \multirow{2}{*}{ Dijital kaynaklarla sınav hazırlayabilirim (örneğin kahoot gibi). } & $\mathrm{f}$ & 4 & 10 & 10 & 9 & 5 \\
\hline & $\%$ & 10.5 & 26.3 & 26.3 & 23.7 & 13.2 \\
\hline \multirow{2}{*}{ Öğrenme ortamını zenginleştirmek için dijital kaynak kullanabilirim } & $\mathrm{f}$ & 0 & 5 & 9 & 17 & 7 \\
\hline & $\%$ & 0 & 13.2 & 23.7 & 44.7 & 18.4 \\
\hline \multirow{2}{*}{ Ders anlatırken dijital kitapları kullanabilirim (e-kitap, z-kitap vb.) } & $\mathrm{f}$ & 3 & 6 & 6 & 15 & 8 \\
\hline & $\%$ & 7.9 & 15.8 & 15.8 & 39.5 & 21.1 \\
\hline \multirow{2}{*}{$\begin{array}{l}\text { Sınıfta yaptığım bir etkinliği paylaşım sitelerine yükleyerek öğrenciyi } \\
\text { motive edebilirim. }\end{array}$} & $\mathrm{f}$ & 2 & 8 & 13 & 8 & 7 \\
\hline & $\%$ & 5.3 & 21.1 & 34.2 & 21.1 & 18.4 \\
\hline \multirow{2}{*}{$\begin{array}{l}\text { Anlattığım dersi dijital ortamda öğrencinin daha sonra da dinleyebilmesini } \\
\text { sağlamak için depolayabilirim }\end{array}$} & $\mathrm{f}$ & 1 & 8 & 12 & 10 & 7 \\
\hline & $\%$ & 2.6 & 21.1 & 31.6 & 26.3 & 18.4 \\
\hline \multirow{2}{*}{ Eğitim öğretim amaçlı video hazırlayabilirim } & $\mathrm{f}$ & 4 & 10 & 10 & 9 & 5 \\
\hline & $\%$ & 10.5 & 26.3 & 26.3 & 23.7 & 13.2 \\
\hline
\end{tabular}

Tablo 2 'ye bakıldığında sınıf öğretmenleri üretim bölümünde çoğunlukla "Sıklıkla” şeklinde, "Dijital kaynaklarla sınav hazırlayabilirim (örneğin kahoot gibi)."ifadesini ve "Eğitim öğretim amaçlı video hazırlayabilirim” ifadesini "ara 
sıra" ve "nadiren" şeklinde; "Sınıfta yaptığım bir etkinliği paylaşım sitelerine yükleyerek öğrenciyi motive edebilirim" ifadesini ve "Anlattı̆̆ım dersi dijital ortamda öğrencinin daha sonra da dinleyebilmesini sağlamak için depolayabilirim" ifadesini "ara sıra" şeklinde yanıtlamışlardır.

Tablo 3. Ölçeğin ikinci boyutu (kaynak kullanımı) ile ilgili yüzde, frekans ve madde ortalamaları

\begin{tabular}{|c|c|c|c|c|c|c|}
\hline Boyutta yer alan maddeler & & 1 & 2 & 3 & 4 & 5 \\
\hline \multirow{2}{*}{ Akıllı tahta kullanabilirim. } & $\mathrm{f}$ & 3 & 3 & 2 & 8 & 22 \\
\hline & $\%$ & 7.9 & 7.9 & 5.3 & 21.1 & 57.9 \\
\hline \multirow{2}{*}{ Eğitim öğretim uygulamalarını cep telefonuma yükleyebilirim. } & $\mathrm{f}$ & 0 & 2 & 5 & 7 & 24 \\
\hline & $\%$ & 0 & 5.3 & 13.2 & 18,4 & 63.2 \\
\hline \multirow{2}{*}{ Tablet kullanabilirim. } & $\mathrm{f}$ & 0 & 2 & 4 & 7 & 25 \\
\hline & $\%$ & 0 & 5.3 & 10.5 & 18.4 & 65.8 \\
\hline \multirow{2}{*}{ Dijital ortamdaki kaynaklara kolaylıkla ulaşabilirim } & $\mathrm{f}$ & 0 & 1 & 2 & 12 & 23 \\
\hline & $\%$ & 0 & 2.6 & 5.3 & 31.6 & 60.5 \\
\hline \multirow{2}{*}{$\begin{array}{l}\text { Öğrenciler ya da velilerle iletişim kurabileceğim bir grup } \\
\text { kurabilirim(örneğin whatsapp grubu). }\end{array}$} & $\mathrm{f}$ & 0 & 0 & 0 & 9 & 29 \\
\hline & $\%$ & 0 & 0 & 0 & 23.7 & 76.3 \\
\hline \multirow{2}{*}{ Eğitimi destekleyen web sitelerinden yararlanabilirim. } & $\mathrm{f}$ & 0 & 0 & 6 & 5 & 27 \\
\hline & $\%$ & 0 & 0 & 15.8 & 13.2 & 71.1 \\
\hline \multirow{2}{*}{ Derste projeksiyon kullanabilirim. } & $\mathrm{f}$ & 0 & 4 & 7 & 6 & 21 \\
\hline & $\%$ & 0 & 10,5 & 18.4 & 15.8 & 55.3 \\
\hline \multirow{2}{*}{$\begin{array}{l}\text { Ders sırasında öğrencinin motivasyonunu arttırmak için dijital } \\
\text { kaynakları kullanabilirim. }\end{array}$} & $\mathrm{f}$ & 0 & 1 & 7 & 8 & 22 \\
\hline & $\%$ & 0 & 2.6 & 18.4 & 21.1 & 57.9 \\
\hline \multirow{2}{*}{ Cep telefonu vb. araçlarla çeşitli içeriklere ulaşabilirim. } & $\mathrm{f}$ & 0 & 0 & 2 & 7 & 29 \\
\hline & $\%$ & 0 & 0 & 5.3 & 18.4 & 76.3 \\
\hline \multirow{2}{*}{$\begin{array}{l}\text { Ders içeriğine göre ihtiyacım olan materyali dijital ortamlarda } \\
\text { bulabilirim. }\end{array}$} & $\mathrm{f}$ & 0 & 0 & 1 & 10 & 27 \\
\hline & $\%$ & 0 & 0 & 2.6 & 26.3 & 71.1 \\
\hline
\end{tabular}

Tablo 3’e bakıldığında sınıf öğretmenlerinin kaynak kullanımı bölümünde çoğunlukla "Her zaman” cevabını verdikleri görülmektedir.

Tablo 4. Ölçeğin üçüncü boyutu (uygulama) ile ilgili yüzde, frekans ve madde ortalamaları

\begin{tabular}{|c|c|c|c|c|c|c|}
\hline Boyutta yer alan maddeler & & 1 & 2 & 3 & 4 & 5 \\
\hline \multirow{2}{*}{ Jpeg /Winzip gibi sıkıştırma formatlarını kullanabilirim } & $\mathrm{f}$ & 9 & 5 & 6 & 9 & 9 \\
\hline & $\%$ & 23.7 & 13.2 & 15.8 & 23.7 & 23.7 \\
\hline \multirow{2}{*}{$\begin{array}{l}\text { Belgeleri farklı formatlara çevirebilirim (örneğin wordden } \\
\text { pdf'ye) }\end{array}$} & $\mathrm{f}$ & 3 & 2 & 8 & 14 & 11 \\
\hline & $\%$ & 7.9 & 5.3 & 21.1 & 36.8 & 28.9 \\
\hline \multirow{2}{*}{$\begin{array}{l}\text { Sosyal İmleme uygulayabilirim (Sosyal İmlem nin amacı } \\
\text { beğenilen içeriklerin sosyal ortamda saklanıp arşivlenmesidir.) }\end{array}$} & $\mathrm{f}$ & 4 & 9 & 7 & 13 & 5 \\
\hline & $\%$ & 10.5 & 23.7 & 18.4 & 34.2 & 13.2 \\
\hline \multirow{2}{*}{$\begin{array}{l}\text { Hazırladığım bir } \quad \text { videoyu } \quad \text { dijital } \\
\text { yükleyebilirim(TeacherTube, Videoegg, Selfcast) }\end{array}$} & $\mathrm{f}$ & 4 & 9 & 7 & 11 & 7 \\
\hline & $\%$ & 10.5 & 23.7 & 18.4 & 28.9 & 18.4 \\
\hline \multirow{2}{*}{ Derste web tabanlı interaktif oyun oynatabilirim. } & $\mathrm{f}$ & 5 & 3 & 11 & 11 & 8 \\
\hline & $\%$ & 13.2 & 7.9 & 28.9 & 28.9 & 21.1 \\
\hline \multirow{2}{*}{$\begin{array}{l}\text { Ders esnasında podcast kullanabilirim.(Podcast'ler genellikle } \\
\text { orijinal ses veya görüntü kayıtlarından oluşur; ancak bir TV } \\
\text { ya da radyo programının, dersin, performansın veya başka bir } \\
\text { etkinliğin kaydedilmiş yayınları da olabilir.) }\end{array}$} & $\mathrm{f}$ & 7 & 8 & 10 & 8 & 5 \\
\hline & $\%$ & 18.4 & 21.1 & 26.3 & 21.1 & 13.2 \\
\hline \multirow{2}{*}{ Eğitim amaçlı bir blog hazırlayabilirim. } & $\mathrm{f}$ & 5 & 9 & 9 & 14 & \\
\hline & $\%$ & 13.2 & 23.7 & 23.7 & 36.8 & \\
\hline \multirow{2}{*}{$\begin{array}{l}\text { Dijital haritaları kullanabilirim (Google Maps, Community } \\
\text { Walk, ZeeMaps, Wayfaring, MapBuzz) }\end{array}$} & $\mathrm{f}$ & 6 & 5 & 7 & 13 & \\
\hline & $\%$ & 15.8 & 13.2 & 18.4 & 34.2 & \\
\hline \multirow{2}{*}{ Dijital ortamda Poster/Kartpostal/Kolaj hazırlayabilirim. } & $\mathrm{f}$ & 6 & 7 & 7 & 12 & \\
\hline & $\%$ & & & & & \\
\hline
\end{tabular}


Tablo 4’e bakıldığında sınıf öğretmenleri uygulamayı kullanabilme bölümünde çoğunlukla "Sıklıkla" şeklinde "Ipeg /Winzip gibi sıkıştırma formatlarını kullanabilirim." ifadesini "Asla" "Sıłlıkla" ve "Her zaman" şeklinde; "Ders esnasında podcast kullanabilirim. (Podcast'ler genellikle orijinal ses veya görüntü kayıtlarından oluşur; ancak bir TV ya da radyo programının, dersin, performansın veya başka bir etkinliğin kaydedilmiş yayınları da olabilir.)" ifadesini "Ara sıra" şeklinde yanıtlamışlardır.

Tablo 5. Ölçeğin dördüncü bölümüne (destek) dair yüzde, frekans ve madde ortalamaları

\begin{tabular}{|c|c|c|c|c|c|c|}
\hline Boyutta yer alan maddeler & & 1 & 2 & 3 & 4 & 5 \\
\hline \multirow{2}{*}{ Öğrencilerime dijital ortamda eğitsel oyunlar oynatabilirim } & $\mathrm{f}$ & 1 & 4 & 7 & 6 & 20 \\
\hline & $\%$ & 2.6 & 10.5 & 18.4 & 15.8 & 52.6 \\
\hline \multirow{2}{*}{$\begin{array}{l}\text { Öğrencilerin öğrenmeyi evde devam ettirebilmeleri için dijital kaynak } \\
\text { kullanabilirim. }\end{array}$} & $\mathrm{f}$ & 2 & 3 & 9 & 10 & 14 \\
\hline & $\%$ & 5.3 & 7.9 & 23.7 & 26.3 & 36.8 \\
\hline \multirow{2}{*}{ Video konferans yöntemi ile tüm öğrencilere ulaşabilirim. } & $\mathrm{f}$ & 3 & 6 & 4 & 12 & 13 \\
\hline & $\%$ & 7.9 & 15.8 & 10.5 & 31.6 & 34.2 \\
\hline \multirow{2}{*}{$\begin{array}{l}\text { Öğrencilerimin çalışmalarını dijital ortamda depolayabilmeleri için dijital port } \\
\text { folyo dosyası hazırlamalarını sağlayabilirim. }\end{array}$} & $\mathrm{f}$ & 6 & 6 & 9 & 9 & 8 \\
\hline & $\%$ & 15.8 & 15.8 & 23.7 & 23.7 & 21.1 \\
\hline \multirow{2}{*}{ Öğrencileri dijital kaynakların kullanımı hakkında bilgilendirebilirim. } & $\mathrm{f}$ & 0 & 8 & 3 & 11 & 16 \\
\hline & $\%$ & 0 & 21.1 & 7.9 & 28.9 & 42.1 \\
\hline
\end{tabular}

Tablo 5’e bakıldığında sınıf öğretmenlerinin destek bölümünde bulunan tüm ifadelere "Her zaman" şeklinde; yalnızca "Öğrencilerimin çalışmalarını dijital ortamda depolayabilmeleri için dijital port folyo dosyası hazırlamalarını sağlayabilirim." ifadesini "Ara sıra” ve "Sıklıkla" şeklinde yanıt verdikleri görülmektedir.

\section{Cinsiyet değişkenini, sinı öğretmenlerinin dijital okuryazarlı öz-yeterliklerinde anlamlı bir boyutta farklilğa sebep olmakta midır?}

Tablo 6. Sinıf öğretmenlerinde cinsiyet değişkeninin üretim ve uygulama kullanabilme bölümlerine ait $T$ - Testi analizi çıktıları

\begin{tabular}{|c|c|c|c|c|c|c|c|}
\hline $\begin{array}{l}\text { Dijital Okuryazarlık } \\
\text { Boyutları }\end{array}$ & Cinsiyet & $\mathrm{N}$ & $\overline{\mathrm{X}}$ & SS & sd & $\mathrm{t}$ & $\mathrm{p}$ \\
\hline Üretim & $\begin{array}{l}\text { Kadin } \\
\text { Erkek }\end{array}$ & $\begin{array}{l}22 \\
16\end{array}$ & $\begin{array}{l}3,42 \\
3,65\end{array}$ & $\begin{array}{l}, 82777 \\
, 68313\end{array}$ & 36 &,- 938. & ,354 \\
\hline $\begin{array}{l}\text { Uygulama } \\
\text { Kullanabilme }\end{array}$ & $\begin{array}{l}\text { Kadin } \\
\text { Erkek }\end{array}$ & $\begin{array}{l}22 \\
16\end{array}$ & $\begin{array}{l}2,88 \\
3,65\end{array}$ & $\begin{array}{r}1,02839 \\
, 88375\end{array}$ & 36 & $-2,433$ & ,020 \\
\hline
\end{tabular}

Tablo 6’ya bakıldığında sınıf öğretmenlerinde üretim ve uygulama kullanabilme bölümlerinde cinsiyete göre değişim olup olmadığını belirlemek için uygulanan bağımsız örneklemler $t$ testi sonuçlarına bakıldığında, cinsiyet değişkeni ile üretim bölümü ( $(36)=, 938 ; \mathrm{p}>.05)$ arasında anlamlı bir farklılık olmadığı, cinsiyet değişkeni ile uygulama kullanabilme bölümü ( $(36)$ 2,433; p<.05) arasında farklılı̆̆ın anlamlı boyutta olduğu tespit edilmiştir.

Dijital okuryazarlık becerisinin üretim bölümünün puanları açısından bakıldığında ise öğretmenlerin cinsiyete göre aldıkları ortalama puanlarının (X Kadın=3,4215, X Erkek=3,6591) hemen hemen aynı olduğu ve istatistiksel olarak anlamlı bir farkın olmadığı anlaşılmaktadır ( $\mathrm{p}=.354)$. Daha önce de yapılan araştırmalar doğrultusunda elde edilen bulgulardan yola çıarak gündelik hayatında kadın öğretmenlerin erkek öğretmenlere göre daha az teknoloji ile etkileşimde oldukları yorumu yapılabilir (Çetin, 2010, s. 160). Erkek öğretmenlerinin uygulama kullanabilme alt boyutunda yer alan puan ortalamalarının (X Erkek=3,6597) kadın öğretmenlerin teknoloji yeterliliği ortalama puanlarından ( $\mathrm{X}$ Kadın=2,8838) daha yüksek olduğu görülmektedir. Bu farkın istatistiksel olarak anlamlılık göstermesi, erkek öğretmenlerin dijital okuryazarlık becerisinin uygulama kullanabilme alt boyutunda kendilerini kadın öğretmenlere göre daha yeterli düzeyde gördükleri sonucuna varılmaktadır. 
Tablo 7. Sınıf öğretmenlerinde cinsiyet değişkeninin kaynak kullanabilme ve destek bölümlerine ait göre Mann-Whitney U Testi analiz sonuçları

\begin{tabular}{lcccccc}
\hline $\begin{array}{l}\text { Dijital Okuryazarlik } \\
\text { Boyutları }\end{array}$ & Cinsiyet & N & Sira Ortalaması & Sira Toplamı & U & P \\
Kaynak & Kadın & 22 & 19,32 & 425,00 & 172,000 &, 904 \\
Kullanabilme & Erkek & 16 & & & & \\
& Total & 38 & 19,75 & 316,00 & & \\
& Kadın & 22 & 19,43 & 427,50 & \\
Destek & Erkek & 16 & & & 313,50 & \\
& Total & 38 & 19,59 & & \\
\hline
\end{tabular}

Tablo 7’ye bakıldığında sınıf öğretmenlerinde kaynak kullanabilme ve destek bölümlerinde cinsiyet değişkenine göre değişim olup olmadığını belirlemek için uygulanan Mann-Whitney U Testi sonuçları incelendiğinde cinsiyet değişkeni ile kaynak kullanabilme ( $U=172.00$, p>.05) ve destek ( $U=174.50, p>.05$ ) bölümleri arasında anlamlı bir farklılı̆̆ın olmadı̆̆ı görülmüştür.

3. Sını öğretmenlerin eğitim durumları dijital okuryazarlık öz yeterlikleri üzerinde anlamlı bir farklılık oluşturmakta midir?

Tablo 8. Sınıf öğretmenlerinde eğitim durumları değişkeninin üretim ve uygulama kullanabilme bölümlerine ait T - Testi analiz sonuçları

\begin{tabular}{cccccccc}
$\begin{array}{c}\text { Dijital Okuryazarlik } \\
\text { Boyutları }\end{array}$ & Cinsiyet & $\mathrm{N}$ & $\overline{\mathbf{X}}$ & $\mathrm{SS}$ & $\mathrm{sd}$ & $\mathrm{t}$ & $\mathrm{p}$ \\
Üretim & lisans & 35 & 3,48 &, 73924 & 36 &,- 907 &, 371 \\
Uygulama & yüksek lisans & 3 & 3,90 & 1,19226 & & & \\
Kullanabilme & lisans & 35 & 3,20 & 1,00967 & 36 & &,- 020 \\
\hline
\end{tabular}

Tablo 8'e bakıldığında sınıf öğretmenlerinde üretim ve uygulama kullanabilme bölümlerinde eğitim durumuna göre değişim olup olmadığını belirlemek için uygulanan bağımsız örneklemler t testi sonuçlarına bakıldığında, eğitim durumu değişkeni ile üretim bölümü $(\mathrm{t}(36)=$,907; p>.05) ve uygulama kullanabilme bölümü $(\mathrm{t}(36), 020$; p>.05) arasında farklılı̆̆ın anlamlı bir boyutta olmadı̆̆ı tespit edilmiştir.

Tablo 9. Sınıf öğretmenlerinde eğitim durumları değişkeninin kaynak kullanabilme ve destek bölümlerine ait MannWhitney U Testi analiz sonuçları

\begin{tabular}{ccccccc} 
Dijital Okuryazarlık & Cinsiyet & N & Sira Ortalaması & Sira Toplamı & U \\
Boyutları & lisans & 35 & 19,26 & 674,00 & 44,000 &, 638 \\
Kaynak Kullanabilme & yüksek lisans & 3 & & & & \\
& Total & 38 & 22,33 & 67,00 & 46,500 &, 744 \\
Destek & lisans & 35 & 19,33 & 676,50 & \\
& yüksek lisans & 3 & & & \\
\hline
\end{tabular}

Tablo 9 incelendiğinde sınıf öğretmenlerinde kaynak kullanabilme ve destek bölümlerinde eğitim durumları değişkenine göre değişim olup olmadığını belirlemek için uygulanan Mann-Whitney U Testi sonuçları incelendiğinde eğitim durumları değişkeni ile kaynak kullanabilme ( $U=44,000, p>.05)$ ve destek ( $U=46,500, p>.05)$ bölümlerinde farklılığın anlamlı bir boyutta olmadı̆̆ı tespit edilmiştir.

\section{Mezun olunan lise türü, sını öğretmenlerinin dijital okuryazarlık öz yeterliliklerinde anlamlı bir boyutta farklılı̆ga} sebep olmakta midir? 
Tablo 10. Sınıf öğretmenlerinin mezun olunan lise türü değişkeninin göre üretim ve uygulama kullanabilme bölümlerine ait T - Testi sonuçları

\begin{tabular}{|c|c|c|c|c|c|c|c|}
\hline Boyutlar & $\begin{array}{l}\text { Mezun olunan lise } \\
\text { türü }\end{array}$ & $\mathrm{N}$ & $\overline{\mathrm{X}}$ & SS & sd & $\mathrm{F}$ & $\mathrm{p}$ \\
\hline \multirow[t]{5}{*}{ Üretim } & Genel Lise & 14 & 3,15 & ,70095 & 3 & 2,239 & , 101 \\
\hline & Anadolu Lisesi & 17 & 3,64 & ,78722 & 34 & & \\
\hline & $\begin{array}{l}\text { Anadolu Öğretmen } \\
\text { Lisesi }\end{array}$ & 6 & 3,87 & ,63158 & 37 & & \\
\hline & Meslek Lisesi & 1 & 4,36 & . & & & \\
\hline & Total & 38 & 3,52 & ,76956 & & & \\
\hline \multirow{5}{*}{$\begin{array}{l}\text { Uygulama } \\
\text { Kullanabilme }\end{array}$} & Genel Lise & 14 & 2,7619 & 89618 & 3 & & \\
\hline & Anadolu Lisesi & 17 & 3,3203 & 1,15996 & 34 & 1,954 & , 139 \\
\hline & $\begin{array}{l}\text { Anadolu Öğretmen } \\
\text { Lisesi }\end{array}$ & 6 & 3,8333 & , 58689 & 37 & & \\
\hline & Meslek Lisesi & 1 & 3,8889 & . & & & \\
\hline & Total & 38 & 3,2105 & 1,03324 & & & \\
\hline
\end{tabular}

Tablo 10’a bakıldığında sınıf öğretmenlerinde üretim ve uygulama kullanabilme bölümlerinde mezun olunan lise türüne göre değişim olup olmadığını belirlemek için uygulanan Tek Yönlü Varyans Analizi (ANOVA) Testi sonuçlarına bakıldığında, mezun olunan lise türü değişkeni ile üretim $(\mathrm{F}(3,34)=2,23 ; \mathrm{p}>.05)$ ve uygulama kullanabilme $(\mathrm{F}(3,34)$, 1,954; p>.05) alt boyutları arasında anlamlı fark bulunamamıştır.

Tablo 11. Sınıf öğretmenlerinde mezun olunan lise türü değişkeninin kaynak kullanabilme ve destek bölümlerine ait Kuruskal Wallis H-Testi Testi analiz sonuçları

\begin{tabular}{|c|c|c|c|c|c|c|}
\hline Boyutlar & $\begin{array}{c}\text { Mezun Olunan Lise } \\
\text { Türü }\end{array}$ & $\mathrm{N}$ & Sira Ort. & sd & $\mathrm{X}^{2}$ & $\mathrm{p}$ \\
\hline \multirow{6}{*}{$\begin{array}{l}\text { Kaynak } \\
\text { Kullanabilme }\end{array}$} & Genel Lise & 14 & 14,82 & \multirow[t]{6}{*}{3} & \multirow[t]{6}{*}{5,049} & \multirow[t]{6}{*}{, 168 } \\
\hline & Anadolu Lisesi & 17 & 21,38 & & & \\
\hline & Anadolu Öğretmen & 6 & 23,00 & & & \\
\hline & Lisesi & & & & & \\
\hline & Meslek Lisesi & 1 & 32,00 & & & \\
\hline & Total & 38 & & & & \\
\hline \multirow[t]{5}{*}{ Destek } & Genel Lise & 14 & 12,11 & \multirow[t]{5}{*}{3} & \multirow[t]{5}{*}{10,439} & \multirow[t]{5}{*}{, 015} \\
\hline & Anadolu Lisesi & 17 & 22,94 & & & \\
\hline & $\begin{array}{l}\text { Anadolu Öğretmen } \\
\text { Lisesi }\end{array}$ & 6 & 26,67 & & & \\
\hline & Meslek Lisesi & 1 & 21,50 & & & \\
\hline & Total & 38 & & & & \\
\hline
\end{tabular}

Tablo 1l'e bakıldığında sınıf öğretmenlerinde kaynak kullanabilme ve destek bölümlerinde mezun olunana lise türü göre değişim olup olmadığını belirlemek için uygulanan Kuruskal Wallis H-Testi sonuçlarına bakıldığında 
mezun olunan lise türünün kaynak kullanabilme alt boyutu $\left(X^{2}(s d=3, n 38)=5,049, p>, 05\right)$ üzerinde anlamlı farkl1lı göstermediği; $\operatorname{destek}\left(\mathrm{X}^{2}(\mathrm{sd}=3, \mathrm{n} 38)=10,439(\mathrm{p}<, 05)\right.$ alt boyutu üzerinde ise anlamlı bir farklılık göstermektedir. Farkın kaynağının meslek lisesi ile diğer liseler arasında, diğer liselerin lehine olduğu anlaşılmaktadır.

\section{Sinıf öğretmenlerin hizmet süreleri dijital okuryazarlık öz-yeterlikleri üzerinde anlamlı bir farklılı oluşturmakta midir?}

Tablo 12. Sınıf öğretmenlerinde hizmet süresi değişkeninin üretim ve uygulama kullanabilme bölümlerine ait tek yönlü varyans analizi (ANOVA) sonuçları

\begin{tabular}{|c|c|c|c|c|c|c|c|}
\hline Boyutlar & Hizmet Süresi & $\mathrm{N}$ & $\overline{\mathrm{X}}$ & SS & sd & $\mathrm{F}$ & p \\
\hline \multirow[t]{4}{*}{ Üretim } & $0-5$ & 26 & 3,60 & ,77527 & 2 &, 506 & ,607 \\
\hline & 6-10 & 11 & 3,32 & 79186, & 35 & & \\
\hline & $11-15$ & 1 & 3,63 & . & 37 & & \\
\hline & Total & 38 & 3,52 & ,76956 & & & \\
\hline \multirow{4}{*}{$\begin{array}{l}\text { Uygulama } \\
\text { Kullanabilme }\end{array}$} & $0-5$ & 26 & 3,26 & ,95642 & 2 & & \\
\hline & $6-10$ & 11 & 3,05 & 1,27305 & 35 & 191 & ,827 \\
\hline & $11-15$ & 1 & 3,44 & . & 37 & & \\
\hline & Total & 38 & 3,21 & 1,03324 & & & \\
\hline
\end{tabular}

Tablo 12'ye bakıldığında sınıf öğretmenlerin üretim ve uygulama kullanabilme bölümlerinde hizmet süresi değişkenine göre değişim olup olmadığını belirlemek için uygulanan Tek Yönlü Varyans Analizi (ANOVA) Testi sonuçlarına bakıldığında, hizmet süresi değişkeni ile üretim $(\mathrm{F}(2,35)=, 506 ; \mathrm{p}>.05)$, uygulama kullanabilme ( $\mathrm{F}$ $(2,35), 191 ; \mathrm{p}>.05)$ alt boyutları arasında anlamlı bir farklılık olmadığı tespit edilmiştir.

Tablo 13. Sınıf öğretmenlerinin hizmet süresi değişkeninin kaynak kullanabilme ve destek bölümlerine ait Kuruskal Wallis H-Testi Testi analiz sonuçları

\begin{tabular}{lcccccc} 
Boyutlar & Hizmet Süresi & $\mathrm{N}$ & Sira Ort. & sd & $\mathrm{X}^{2}$ & $\mathrm{p}$ \\
Kaynak & $0-5$ & 26 & 21,38 & 2 & 2,817 & \\
Kullanabilme & $6-10$ & 11 & 14,86 & & \\
& $11-15$ & 1 & 21,50 & & \\
& Total & 38 & & & \\
Destek & $0-5$ & 26 & 21,29 & 2 & 2,150 &, 341 \\
& $6-10$ & 11 & 15,64 & & & \\
& $11-15$ & 1 & 15,50 & & & \\
& Total & 38 & & & & \\
\hline
\end{tabular}

Tablo 13’e bakıldığında sınıf öğretmenlerinde kaynak kullanabilme ve destek bölümlerinde hizmet süresi değişkenine göre değişim olup olmadığını belirlemek için uygulanan Kuruskal Wallis H-Testi sonuçlarına bakıldığında eğitim durumlarının kaynak kullanabilme $\left(X^{2}(s d=2, n 38)=2,817, p>, 05\right)$ ve $\operatorname{destek}\left(X^{2}(s d=2, n 38)=2,150, p>, 05\right)$ bölümleri arasında anlamlı farklılık bulunamamıştır.

6. Sını öğretmenlerin yaşları dijital okuryazarlık öz yeterlilikleri üzerinde anlamlı bir farklılık oluşturmakta mıdır? 
Tablo 14. Sınıf öğretmenlerinin yaş değişkeninin üretim ve uygulama kullanabilme bölümlerine göre tek yönlü varyans analizi ( ANOVA) sonuçları

\begin{tabular}{|c|c|c|c|c|c|c|c|}
\hline Boyutlar & Yaş & $\mathrm{N}$ & $\overline{\mathrm{X}}$ & SS & sd & $\mathrm{F}$ & $\mathrm{p}$ \\
\hline \multirow[t]{5}{*}{ Üretim } & $20-24$ & 5 & 3,38 & ,44257 & 3 & \multirow{5}{*}{,144 } & \multirow{5}{*}{,933 } \\
\hline & $25-29$ & 18 & 3,60 & ,93656 & 34 & & \\
\hline & $30-34$ & 14 & 3,46 & ,67605 & 37 & & \\
\hline & $35-39$ & 1 & 3,63 & . & & & \\
\hline & Total & 38 & 3,52 & ,76956 & & & \\
\hline \multirow{5}{*}{$\begin{array}{l}\text { Uygulama } \\
\text { Kullanabilme }\end{array}$} & $20-24$ & 5 & 2,77 & 1,10275 & 3 & \multirow{5}{*}{,351 } & \multirow{5}{*}{,789 } \\
\hline & $25-29$ & 18 & 3,31 & 1,19260 & 34 & & \\
\hline & $30-34$ & 14 & 3,21 & ,84447 & 37 & & \\
\hline & $35-39$ & 1 & 3,44 & . & & & \\
\hline & Total & 38 & 3,21 & 1,03324 & & & \\
\hline
\end{tabular}

Tablo 14'e bakıldığında sınıf öğretmenlerinde üretim ve uygulama kullanabilme bölümlerinde yaş değişkenine göre değişimin olup olmadığını belirlemek için uygulanan Tek Yönlü Varyans Analizi ( ANOVA) Testi sonuçlarına bakıldığında, yaş değişkeni ile üretim $(\mathrm{F}(3,34)=, 144 ; \mathrm{p}>.05)$ ve uygulama kullanabilme $(\mathrm{F}(3,34), 789 ; \mathrm{p}>.05)$ alt boyutları arasında anlamlı bir farklılık olmadığı tespit edilmiştir.

Tablo 15. Sınıf öğretmenlerinde yaş değiş̧keninin kaynak kullanabilme ve destek bölümlerine ait Kuruskal Wallis H-Testi Testi analiz sonuçları

$\begin{array}{lcccccc}\text { Boyutlar } & \text { Yaş } & \mathrm{N} & \text { Sira Ort. } & \text { sd } & \mathrm{X}^{2} & \mathrm{p} \\ \text { Kaynak } & 20-24 & 5 & 17,70 & 3 & 2,515 & , 473 \\ \text { Kullanabilme } & 25-29 & 18 & 22,31 & & & \\ & 30-34 & 14 & 16,39 & & \\ & 35-39 & 1 & 21,50 & & 2,224 & , 527 \\ & \text { Total } & 38 & & & \\ \text { Destek } & 20-24 & 5 & 20,20 & & \\ & 25-29 & 18 & 22,00 & & & \\ & 30-34 & 14 & 16,32 & & & \\ & 35-39 & 38 & 15,50 & & & \\ & \text { Total } & & & & & \\ \end{array}$

Tablo 15’e bakılıdığında sınıf öğretmenlerinin kaynak kullanabilme ve destek bölümlerinde yaş değişkenine göre değişimin olup olmadığını belirlemek için uygulanan Kuruskal Wallis H-Testi sonuçlarına bakıldığında yaşın kaynak kullanabilme $\left(\mathrm{X}^{2}(\mathrm{sd}=3, \mathrm{n}=38)=2,515, \mathrm{p}>, 05\right)$ ve $\operatorname{destek}\left(\mathrm{X}^{2}(\mathrm{sd}=3, \mathrm{n}=38)=2,224, \mathrm{p}>, 05\right)$ alt boyutları arasinda anlaml farklılık bulunamamıștır

7. Sinı öğretmenlerin bilgisayara erişim imkânlarının dijital okuryazarlık öz-yeterlikleri üzerinde anlamlı bir farklılık oluşturmakta mıdır? 
Tablo 16. Sınıf öğretmenlerinde bilgisayara erişim imkânı değişkeninin üretim ve uygulama kullanabilme bölümlerine ait T - Testi analiz sonuçları

\begin{tabular}{lccccccc} 
Dijital Okuryazarlık & $\begin{array}{c}\text { Bilgisayara } \\
\text { Erişim İmkanı }\end{array}$ & $\mathrm{N}$ & $\overline{\mathrm{X}}$ & $\mathrm{SS}$ & $\mathrm{sd}$ & $\mathrm{t}$ & $\mathrm{p}$ \\
Boyutları & Var & 37 & 3,5111 &, 77742 & 36 &, 505 &, 616 \\
Üretim & Yok & 1 & 3,9091 &. & & \multirow{2}{*}{, 119} &, 906 \\
Uygulama & Var & 37 & 3,2072 & 1,04729 & 36 & & \\
Kullanabilme & Yok & 1 & 3,3333 &. & & & \\
\hline
\end{tabular}

Tablo 16’ya bakıldığında sınıf öğretmenlerinde üretim ve uygulama kullanabilme bölümlerinde bilgisayara erişim imkanına göre değişimin olup olmadığını belirlemek için uygulanan bağımsız örneklemler $t$ testi sonuçlarına bakıldığında, bilgisayara erişim imkanı değişkeni ile üretim alt boyutu $(\mathrm{t}(36)=, 505 ; \mathrm{p}>.05)$ ve uygulama kullanabilme bölümleri ( $\mathrm{t}(36), 119$; p >.05) arasında anlamlı bir farklılığın olmadığı tespit edilmiştir.

Tablo 17. Sınıf öğretmenlerinde bilgisayara erişim imkanı değişkeninin kaynak kullanabilme ve destek bölümlerine ait Mann-Whitney U Testi analiz sonuçları

\begin{tabular}{|c|c|c|c|c|c|c|}
\hline $\begin{array}{l}\text { Dijital Okuryazarlık } \\
\text { Boyutları }\end{array}$ & $\begin{array}{c}\text { Bilgisayara Erişim } \\
\text { İmkanı }\end{array}$ & $\mathrm{N}$ & $\begin{array}{c}\text { Sira } \\
\text { Ortalamasi }\end{array}$ & Sira Toplamı & $\mathrm{U}$ & $\mathrm{P}$ \\
\hline \multirow[t]{3}{*}{ Kaynak Kullanabilme } & Var & 37 & 19,89 & 736,00 & 4,000 & ,176 \\
\hline & Yok & 1 & & & & \\
\hline & Total & 38 & 5,00 & 5,00 & & \\
\hline \multirow[t]{4}{*}{ Destek } & Var & 37 & 19,45 & 719,50 & 16,500 & ,855 \\
\hline & Yok & 1 & & & & \\
\hline & Total & 38 & & 21,50 & & \\
\hline & & & 21,50 & & & \\
\hline
\end{tabular}

Tablo 17’ye bakıldığında sınıf öğretmenlerinde kaynak kullanabilme ve destek bölümlerinde bilgisayara erişim imkânı değişkenine göre değişimin olup olmadığını belirlemek için uygulanan Mann-Whitney U Testi sonuçlarına bakıldığında bilgisayara erişim imkanı değişkeni ile kaynak kullanabilme $(\mathrm{U}=4,000, \mathrm{p}>.05)$ ve destek $(\mathrm{U}=16,500$, p>.05) bölümlerinin arasında anlamlı bir farklılı̆̆ı çıkmadığı görülmüştür.

\section{SONUC}

$\mathrm{Bu}$ çalışmada sınıf öğretmenlerinin kendilerine yönelik dijital okuryazarlık öz yeterlikleri üzerinde cinsiyet, yaş, eğitim durumu, mezun olunan lise türü, hizmet süresi, bilgisayara erişim imkanı gibi değişkenlerin anlamlı bir farklılık oluşturup oluşturmadığı incelenmek istenmiştir.

Ölçeğin her bir alt boyutu öğretmenlerin vermiş oldukları cevaplar doğrultusunda incelenmiştir. Ölçeğin gerek alt boyutları gerekse bütünü incelendiğinde katılımcıların çoğunlukla "sıklıkla" cevabını verdikleri gözlemlenmiştir. Bu durum sınıf öğretmenlerinin kendilerine yönelik dijital okuryazarlık alanında gerekli beceriye sahip olduklarını düşündüklerini göstermektedir. Konu üzerine yapılan araştırmalarda da ifade edildiği üzere öğretmenlerin dijital okuryazar bireyler olmaları gerektiği, fakat eğitim aracı olarak kullanma noktasında eksik oldukları, bu açığın giderilmesi adına öğretmen eğitimlerinin gerekli planlamalarla şekillendirilmesi gerektiği belirtilerek bu noktalar son derece önem taşımaktadır (Ocak ve Karkuş,2019, s. 131). Usta ve Korkmaz (2010)'ın da yapmış oldukları çalışmada belirttikleri üzere, özellikle eğitim fakültelerinde teknolojiyi kullanma noktasında gerekli donanımın sağlanması eğitimin kalitesini olumlu yönde etkileyen faydalı adımlar olarak kabul edilmektedir. Bireylerin teknolojiyi doğru kullanmaları noktasında öncelikle öğretmenlerin teknoloji kullanımına karşı olumlu tutum geliştirmeleri gerekmektedir. Geliştirilecek olumlu tutumların teknolojiyi kullanabilme konusunda da önemli katkılar sağladığı belirtilmektedir.

İkinci alt problemde cinsiyet faktörünün dijital okuryazarlık öz-yeterlikleri üzerindeki etkisi ele alınmıştır. Varılan sonuca göre sınıf öğretmenlerinin dijital okuryazarlık öz-yeterlik seviyeleri üzerinde cinsiyet faktörünün yalnızca araştırmada yer alan uygulama kullanabilme alt boyutunda anlamlı bir farklılığa sebep olduğu diğer boyutlarda ise anlamlı bir farklılığın oluşmasına neden olmadığı görülmektedir. Çetin, Çalışkan ve Menzi (2012) tarafından gerçekleştirilen araştırmada ise teknoloji yeterliliğe erkek öğretmen adaylarının kadın öğretmen adaylarına kıyasla 
daha iyi durumda oldukları fakat, cinsiyet değişkenine göre bireylerin teknolojiye yönelik tutumlarında farklılığın oluşmadığı belirtilmiştir. Yontar (2019), yapmış olduğu çalışmada erkek öğretmen adaylarının dijital okuryazarlık düzeylerinin kadın öğretmen adaylarınınkinden daha yüksek bulmuştur ve bu durumu erkeklerin teknolojik araç gereçlere olan ilgi ve meraklarının kadınlara göre daha fazla olmasına bağlamaktadır. Diğer yapılan çalışmalara bakıldığında araştırmacıların çalışmalarında Medya Okuryazarlı̆̆ı Düzey Belirleme Ölçeğini kullandıklarına rastlanmıştır. Medya Okuryazarlığı Düzey Belirleme Ölçeği kullanılarak elde edilen sonuçlarda cinsiyet bakımından bir farklılaşma olmadığı görülmüştür (Karasu ve Arıkan, 2016, s. 556).

Çalışmada üçüncü alt problem olarak sınıf öğretmenlerinin eğitim durumlarının dijital okuryazarlık öz-yeterlikleri üzerindeki etkisi incelenmiştir. Yapılan inceleme ile sınıf öğretmenlerinin eğitim durumlarının dijital okuryazarlık öz-yeterlilikleri konusunda farklılığın anlamlı bir boyutta olmadığı tespit edilmiştir.

Araştırmada dördüncü alt problem olarak sınıf öğretmenlerinin mezun oldukları lise türünün dijital okuryazarlık öz-yeterlikleri üzerindeki etkisi incelenmiştir. Destek alt boyutunda inceleme sonucunda anlamlı farklılık bulunup diğer sözü edilen alt boyutlarda anlamlı farklılık gözlemlenememiştir. Farkın Meslek Liseleri ve diğer liselere bakıldığında, diğer liselerin lehine olduğu anlaşılmaktadır. Meslek lisesi mezunu 1 öğretmen olduğu için bu anlamda bir genelleme yapmak doğru olmayacaktır.

Beşinci alt problem olarak sınıf öğretmenlerinin hizmet sürelerinin dijital okuryazarlık öz-yeterlikleri üzerindeki etkisi incelendiğinde sözü edilen değişken ile alt boyutlar arasında anlamlı bir farklılık gözlemlenememiştir.

Çalışmanın altıncı alt problemi olarak sınıf öğretmenlerinin yaşlarını dijital okuryazarlık öz-yeterlikleri üzerindeki etkisi incelenmiştir bu noktada farklılığın anlamlı düzeyde olmadığı sonucuna varılmıştır.

Çalışmanın yedinci alt probleminde ise sınıf öğretmenlerinin bilgisayara olan erişimlerinin dijital okuryazarlık öz-yeterlikleri üzerindeki etkisi incelendiğinde araştırmaya katılan öğretenlerden sadece bir tanesinin bilgisayara erişiminin olmadığı belirtilerek aralarında anlamlı farklılığın bulunmadığı görülmektedir.

\section{ÖNERILER}

Yapılan araştırmadan elde edilen sonuçların daha kapsamlı bir şekilde incelenip çıkarımlarda bulunulması için anketin daha geniş bir kitleye uygulanması, çalışmaya fayda sağlayacaktır. Bu çalışma sadece sınıf öğretmeleri ile gerçekleştirilmiştir, branş öğretmenleri de araştırmaya dahil edilerek daha kapsamlı bir sonuç elde edilebilir.

\section{KAYNAKÇA}

Akkoyunlu, B., Sağlam, N. ve Atav, E. (2004, Kasım). Ögretmen adaylarının internet kullanım sıklık ve amaçları. IV. Uluslararası Eğitim Teknoloji/eri Sempozyumu.Sakarya.

Aksu Bektaş, Y., Alver, M. (2020). Medya okuryazarlığı dersine ilişkin öğrenci tutumları ile öğretmen ve öğretmen adayı görüşlerinin değerlendirilmesi. Mersin Üniversitesi Eğitim Fakültesi Dergisi, 16(3),546-572.

Altun, A. (2005). Gelişen teknolojiler ve yeni okuryazarlıklar. Ankara: Anı Yayıncılık.

Budak, Y., Öztürk, Y. (2019). Öğretmen adaylarının kendilerine yönelik dijital okuryazarlık değerlendirmelerinin incelenmesi. Kesit Akademi Dergisi,21, 156-172.

Büyüköztürk, Ş., Kılıç Çakmak, E., Akgün, Ö. E., Karadeniz, Ş ve Demirel, F. (2014) Eğitimde bilimsel araştırma yöntemleri (25. Baskı). Ankara: Pegem Akademi.

Çakmak,E. E. (2019). Öğretmenlerin medya okuryazarlık düzeylerinin incelenmesi. Sınırsız Eğitim ve Araştırma Dergisi, (4)3, $300-316$

Çetin, O. (2010). Fen ve teknoloji dersinde "çoklu ortam tasarım modeli”ne göre hazırlanmış web tabanlı öğretim içeriğinin öğrenci başarı ve tutumlarına etkisi ile içeriğe yönelik öğretmen ve öğrenci görüşlerinin değerlendirilmesi (Yayımlanmamış doktora tezi). Dokuz Eylül Üniversitesi, Eğitim Bilimleri Enstitüsü, İzmir.

Çetin, O., Çalışkan, E. ve Menzi, N. (2012). Öğretmen adaylarının teknoloji yeterlilikleri ile teknolojiye yönelik tutumları arasındaki ilişki İlköğretim Online, 11(2), 273-291.

Çetin, O., Çalışkan, E., \& Menzi, N. (2012). Öğretmen adaylarının teknoloji yeterlilikleri ile teknolojiye yönelik tutumları arasındaki ilişki. İlköğretim Online, 11(2). 
Hamutoğlu, B., N., Canan Güngören, Ö., Kaya Uyanık, G. Ve Gür Erdoğan, D. (2017). Dijital okuryazarlık ölçeği: Türkçe 'ye uyarlama çalışması. Ege Eğitim Dergisi 2017(18) 1, 408 - 429.

Karabacak, Z., İ. ve Sezgin, A., A. (2019). Türkiye’de dijital dönüşüm ve dijital okuryazarlık. Türkiye İdare Dergisi, (488), $319-343$.

Karasu, M. ve Arıkan, D. (2016). Öğretmen adaylarının sosyal medya kullanım durumları ve medya okuryazarlık düzeyleri arasındaki ilişkinin incelenmesi. Ege Eğitim Dergisi ,17 (2), 549-566.

Ocak, G., Karakuş, G. (2019). Öğretmen adaylarının dijital okuryazarlık öz-yeterlilik becerilerinin farklı değişkenler açısından incelenmesi. Afyon Kocatepe Üniversitesi Sosyal Bilimler Dergisi, (2)1, 129-147.

Önal, İ. (2010). Tarihsel değişim sürecinde yaşam boyu öğrenme ve okuryazarlık: Türkiye deneyimi. Bilgi Dünyası, 11(1), 101121.

Tinmaz, H. (2004). An assessment of preservice teachers' technology perception in relation to their subject area (Yayımlanmamış yüksek lisans tezi). Orta Doğu Teknik Üniversitesi, Sosyal Bilimler Enstitüsü, Ankara.

Türkoğlu, T. (2010). Dijital kültür. İstanbul: Beyaz Yayınları

Ulusoy, A. (2018). Dijital medya okuryazarlığı, gereksinimler ve yeni uygulamalar üzerine bir inceleme. (Doktora tezi). Erciyes Üniversitesi, Sosyal Bilimler Enstitüsü, Kayseri.

Usta, E. ve Korkmaz, Ö. (2010). Öğretmen adaylarının bilgisayar yeterlikleri ve teknoloji kullanımına ilişkin algıları ile öğretmenlik mesleğine yönelik tutumları. Uluslararası İnsan Bilimleri Dergisi. 7 (1), 1335-1349.

Usta, E. ve Korkmaz, Ö. (2010). Öğretmen adaylarının bilgisayar yeterlikleri ve teknoloji kullanımına ilişkin algıları ile öğretmenlik mesleğine yönelik tutumları. Uluslararası İnsan Bilimleri Dergisi, 7 (1), 1335-1349.

Üstündağ, T., M., Güneş ve E., Bahçivan, E. (2017). Dijital okuryazarlık ölçeğinin Türkçeye uyarlanması ve fen bilgisi öğretmen adaylarının dijital okuryazarlık durumları. Journal of Education and Future, 12, 19-29.

Yılmaz, B. (1989). Okuryazarlık ve okuma alışkanlığı üzerine. Türk Kütüphaneciliği, 3(1), 48-53.

Yontar, A. (2019). Öğretmen adaylarının dijital okuryazarlık düzeyleri. Ana Dili Eğitimi Dergisi, 7(4), 815-824. 


\title{
Investigation of Digital Literacy Levels of Classroom Teachers in Terms of Different Variables
}

\author{
Hanife KESKIN (D), Gonca KÜÇÜK (iD)
}

Raising individuals that can keep up with the times, one of the most basic conditions for the progress of a society, is only possible with education appropriate for the age. As long as education progresses in parallel with the current age, it keeps its timeliness and ensures that individuals who can keep up with the times are raised in a healthier way. Making education suitable for the current era will be possible if the educators have age-specific skills. The age we live in makes it necessary to use technology in the best way. Failure to gain the skills for the use of technology will push the society behind the times and prevent the progress of the society. Mistakes made in this direction will cause the society to encounter situations that are difficult to recover by experiencing great losses. The education that shapes the society should be evaluated well in this context and necessary innovations should be integrated into education with the progress of the age. It is of great importance to have digital literacy skills at the point of understanding and using technology. As Önal (2010) states, the concept of literacy gains different meanings with the advancement of the age and the future is shaped according to this concept of literacy. Ocak and Karakuş (2019) stated that digital literacy does not only mean using technological tools; but it also includes complex cognitive, sociological and emotional skills. In Yontar (2019)'s study, the concept of digital literacy was expressed as being able to evaluate from multiple perspectives, such as being able to access information from digital sources, as well as making necessary comments by comparing the information obtained from these sources with the existing information. Therefore, it is important to acquire and gain these skills through education. Acquiring digital literacy skills and using them in educational environments will make education more effective and ensure that education is age-appropriate. The development of a society is possible by providing individuals with age-appropriate education.

In today's conditions, technology has gained a great place in education. It should be ensured that the teachers who provide education have the necessary equipment in this direction (Yontar, 2019, p. 816). First of all, teachers need to be aware of their digital literacy levels and see the aspects that need to be improved and fill these deficiencies in the most effective way. Therefore, it is of great importance for them to know their digital literacy levels and to develop predictive tools in this direction. With the help of these tools, the current situation should be determined and required studies should be planned and carried out. It will be a guide for the planning and measurements to reveal the reasons why digital literacy levels change from person to person. Authorities are required to carry out the process by planning, and to make arrangements by receiving the necessary feedback at the end of the process. In addition to ensuring that educators have the necessary equipment, educational environments need to be improved in this context. The necessary infrastructure should be provided to the schools, educators and students should come together, the process should be ensured to pass in the most effective way, and necessary arrangements should be made by considering the feedback about the process.

This study was carried out to measure the digital literacy levels of classroom teachers in terms of different variables. In addition, it was aimed to reveal whether gender, education status, length of service, type of high school they graduated from, age, and computer access opportunities have an effect on the digital literacy levels of classroom teachers. The sub-dimensions of digital literacy were handled as resource use, application use and support. Necessary measures should be taken or plans should be made considering the effect of these variables on the digital literacy of 
individuals. For this purpose, the "Digital Literacy Self-Efficacy Scale of Pre-service Teachers" developed by Ocak and Karakuş (2018), a Cronbach-Alpha likert type scale with an internal consistency of 0.908, was used in the study. The data were analyzed with the SPSS 22.0 program. The study was carried out with 38 classroom teachers working in Şanlıurfa Eyyübiye Ahmet Hamdi Akseki Primary School, and voluntary participation was ensured. After the research, it was concluded that the digital literacy self-efficacy of the teachers was high, and it was observed that there were significant differences in each sub-dimension of gender and the type of high school graduated.

Keywords: Digital literacy, classroom teachers, the Internet.. 